\title{
Modern technology of construction of underground part of buildings in urban conditions
}

\author{
Sergey Sinenko ${ }^{1}$, Liliya Pakhomova $^{1}$, and Alexandra Chernyshova ${ }^{1, *}$ \\ ${ }^{1}$ Moscow State University of Civil Engineering, 129337, 26, Yaroslavskoye Shosse, Moscow, Russia
}

\begin{abstract}
It is considered the construction of the underground part of buildings and structures by "Moscow method", the essence of which is an arranging of pit's enclosing structure - "wall in ground" in common with the underground part of a building, when pit enclosure is braced in outward thrust with disks of major floors of the underground part of the erecting building, which are connected to each other by a system of spacers, suspensions and racks forming support structure. The positive and negative features of the method are given. The article summarizes the experience of this method, which is advisable to use in construction of the underground part of buildings or structures in cramped urban conditions, provided that the enclosing structure of a pit is "wall in ground". One highlights the stages and gives the main specific features of the method. It is shown that this method leads to a reduction of work costs at the zero cycle, but it increases the duration of work.
\end{abstract}

\section{Introduction}

The technologies for multistorey buildings construction, including high-rise residential buildings, have been significantly developed in modern domestic construction for the last decade. Construction of buildings is performed according to building point scheme on the limited territory with dimensions of 600-18000 $\mathrm{m} 2$ in urban areas.

The construction quality and its economic indicators for such facilities are primarily based on the correct choice of rational organization type and technology of work during preparatory period and foundations arrangement.

The main problem of zero cycles construction in urban development is Customer's will to utilyze the entire allotted area for construction to accommodate a building, as a consequence, the lack of construction site in the traditional view (with roads, storage areas, temporary construction camp, etc.) [1-8]. The erection of building or structure underground part by "Moscow method" (Russia) allowes to construct a building partly by "top-down" method using covering underground part to the needs of construction (a suspended ceiling at elevation \pm 0.00 ).

*Corresponding author: liliya_7172@mail.ru 
The essence of " Moscow method " is that the "wall in ground" is not bursting with a spacer system of massive metal structures, but inventory steel spacers (farms, assembled on site of light metal elements) and floor discs of building or structure underground part $[1,2]$.

\section{Materials and methods}

The technology of structures construction by "Moscow method" (patent RF2220258) [1]: bracing of the pit is done by connecting to each other of two main floors ( $3 \mathrm{~d}$ and 4 th) by braces and racks (trusses), which form a spatial long-span structure, rested on the "wall in ground", ground pillars (developed as lowering down) and intermediate supports installed on the foundation, see Fig.1

Technology of structures erection by "Moscow method"

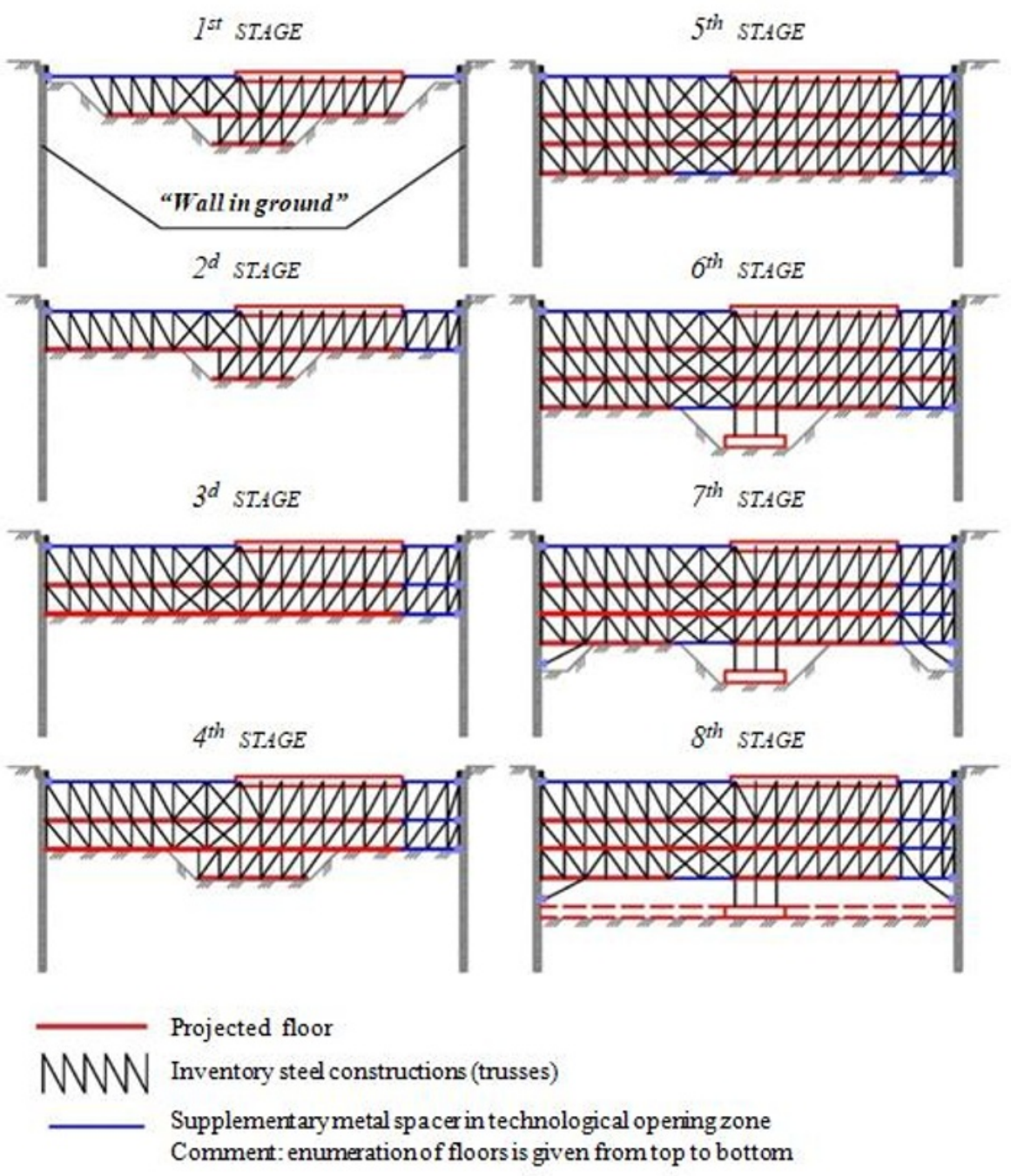

Fig. 1. Scheme of temporary spacer constructions arrangement while performing the proposed technology. 
The "Moscow method" of building underground part erection assumes the following stages to be executed:

1 st stage - pioneer pit development with earth pillars, soil at the bottom of the pit and on pillars is compacted for part of floors concreting (floor 2,3), jointly with mortgage details of trusses, then elements of trusses are mounted and it is concreted a part of floor (floor 1,2) in opening technological area (through which the grapple will excavate the soil, developed by compact construction equipment, working under the floor; truss elements and concrete will be feeding in), metal spacers are installed.

$2 \mathrm{~d}$ stage - soil is excavated, the floors 1 and 2 are finally concreting. After strength gain the floor 1 can be used, upon a designer agreement, for construction equipment and temporary construction camp arrangement.

$3 \mathrm{~d}$ stage - soil excavation, mounting of trusses elements and final concreting of the floor 3.

4th stage - soil excavation, part of the floor 4 concreting, mounting of trusses elements.

5 th stage - soil excavation, the floor 4 final concreting, mounting of trusses elements.

6 th stage - soil excavation, part of the main floor arrangement, installation of temporary pillars.

7th stage - soil excavation, mounting of braces.

8th stage - soil excavation, the main floor final concreting.

Implementation of these stages allows to perform arrangement of vertical structures at full height of the underground part of the projected building (columns, exterior and interior walls, elevator shafts and stairs). This ensures proper working conditions and safety.

The inventory spacers are presented on Fig. 2.
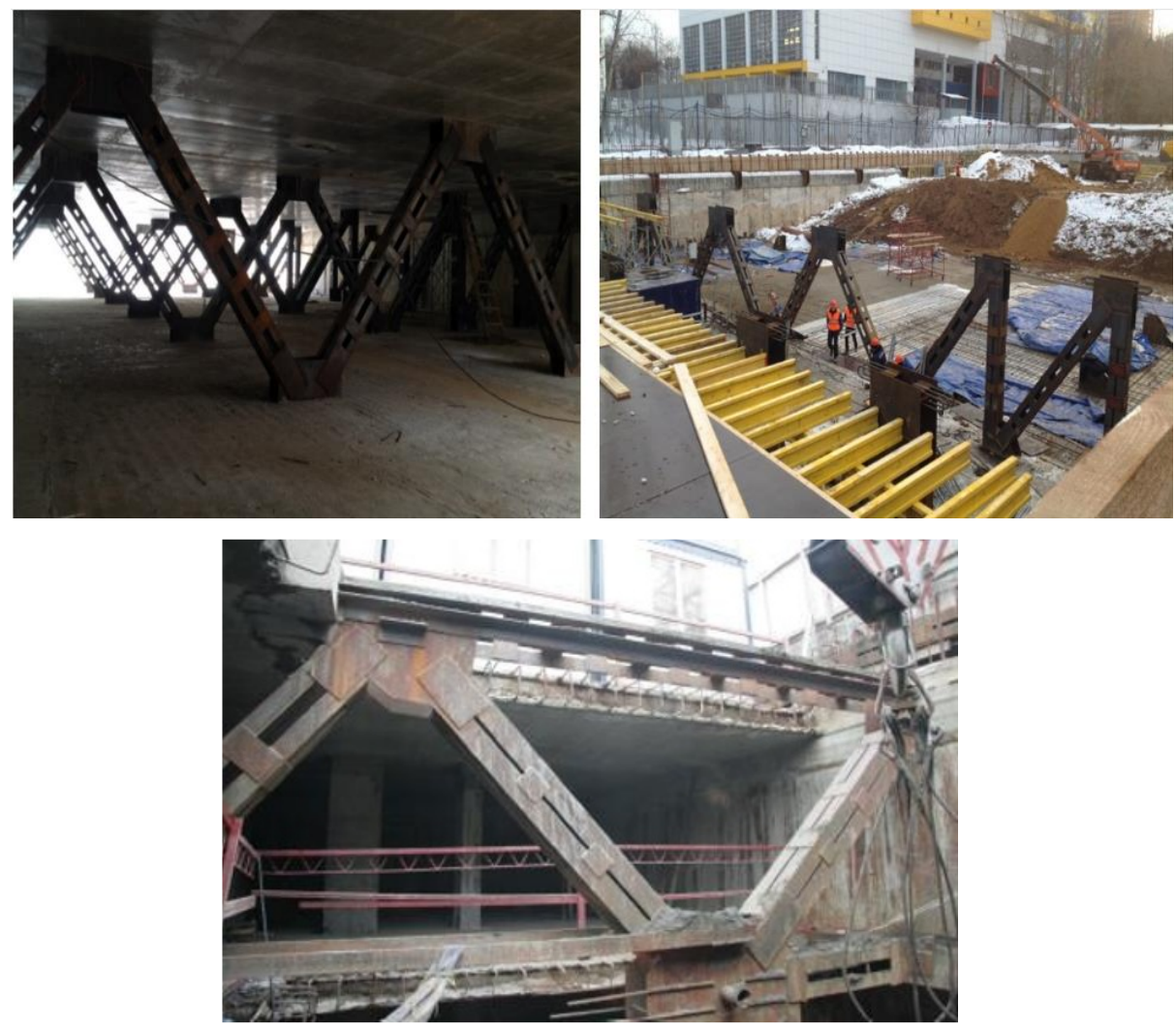

Fig. 2. Inventory steel spacers. 
After concrete is gaining the projected strength one perfoms phase dismounting of temporary spatial spacer system. The above mentione method has variety of modifications and designe solutions depending on construction conditions and erecting structures.

\section{Results}

The "Moscow method" is well established in cramped construction conditions, such a pit fixing allows:

- to lower movement and deformation of soil array;

- to use pit area for construction needs;

- to reduce consumption of steel for temporary bracing;

- to reduce operation costs of zero cycle, increasing duration of works.

Table 1. Options.

\begin{tabular}{|c|c|c|c|c|}
\hline No & Name of work & $\begin{array}{l}\text { Option } 1 \\
\text { Traditional }\end{array}$ & $\begin{array}{l}\text { Option2 } \\
\text { Moscow method }\end{array}$ & Notes \\
\hline 1 & $\begin{array}{l}\text { Trench for the wall at } \\
\text { soil }\end{array}$ & $\begin{array}{l}6130 \mathrm{~m} 3 \\
40.000 \text { thousands } \\
\text { rubbles }\end{array}$ & $\begin{array}{l}5040 . \mathrm{m} 3 \\
32000 \text { thousands } \\
\text { rubbles }\end{array}$ & $\begin{array}{l}\text { Grapple under Bentonitesu } \\
\text { spension }\end{array}$ \\
\hline 2 & $\begin{array}{l}\text { Monolithic reinforced } \\
\text { concrete structures for } \\
\text { Walls at soil }\end{array}$ & - & $\begin{array}{l}1800 \mathrm{~m} 3 \\
40000 \text { thousands } \\
\text { rubbles }\end{array}$ & From delivery to site \\
\hline 3 & $\begin{array}{l}\text { Frameworks for walls at } \\
\text { soil }\end{array}$ & $\begin{array}{l}740 \mathrm{~T} \\
40.000 \text { thousands } \\
\text { rubbles }\end{array}$ & $\begin{array}{l}220 \mathrm{~T} \\
12.000\end{array}$ & From delivery to site \\
\hline 4 & $\begin{array}{l}\text { Steel Frames, monolithic } \\
\text { works }\end{array}$ & $\begin{array}{l}6979 \mathrm{~m} 3 \\
60.000 \text { thousands } \\
\text { rubbles }\end{array}$ & $\begin{array}{l}3680 \mathrm{~m} 3 \\
35.000\end{array}$ & - \\
\hline 5 & Steel Stronghold & $\begin{array}{l}890 \mathrm{~T} \\
59.000 \text { thousands } \\
\text { rubbles }\end{array}$ & $\begin{array}{l}410 \mathrm{~T} \\
32.000 \text { thousands } \\
\text { rubbles }\end{array}$ & Var1 2 level var2 3 tier. \\
\hline 6 & Waterproofing Walls & $\begin{array}{l}3900 \mathrm{~m} 2 \\
6.000 \text { thousands rubbles }\end{array}$ & $\begin{array}{l}4000 \mathrm{pm} \\
4.000 \text { thousands } \\
\text { rubbles }\end{array}$ & $\begin{array}{l}\text { Option } 1 \\
\text { Glued } \\
\text { Option } 2 \\
\text { The throne }\end{array}$ \\
\hline 7 & $\begin{array}{l}\text { Monolithic reinforced } \\
\text { concrete structures }\end{array}$ & $\begin{array}{l}7000 \mathrm{~m} 3 \text { from account } \\
\text { for outdoor walls } \\
149.000 \text { thousands } \\
\text { rubbles }\end{array}$ & $\begin{array}{l}5900 \mathrm{~m} 3 \text { without } \\
\text { outdoor walls } \\
134.000 \text { thousands } \\
\text { rubbles }\end{array}$ & $\begin{array}{l}\text { Walls, pillars overlapping } \\
\text { Without foundations, ramp } \\
\text { s, stairs }\end{array}$ \\
\hline 8 & Soil works & $\begin{array}{l}66000 \mathrm{~m} 3+ \\
40.000 \text { thousands } \\
\text { rubbles }\end{array}$ & $\begin{array}{l}66000 \mathrm{~m} 3 \\
49000 \text { thousands } \\
\text { rubbles }\end{array}$ & - \\
\hline \multirow[t]{2}{*}{9} & Licensed Payments & - & $\begin{array}{l}6.000 \text { thousands } \\
\text { rubbles }\end{array}$ & - \\
\hline & TOTAL & $\begin{array}{l}394.000 \text { thousands } \\
\text { rubbles } \\
100 \%\end{array}$ & $\begin{array}{l}344.000 \text { thousands } \\
\text { rubbles } \\
87 \%\end{array}$ & At current reference prices \\
\hline
\end{tabular}




\section{Conclusion}

Now the "Moscow method" of temporary spacer constructions erection becomes more and more popular, and already occupies its niche in construction. Under certain conditions of construction, usually cramped, this method is the most rational way of construction of the underground part of buildings or structures.

The following buildings and structures were erected by this method:

1. Underground 6-storey garage on Turgenev square. The pit foundation was made by four main floors of variable thickness, combined into a spatial supporting structure with spacers and racks. It was designed for the installation of excavating equipment (grab weighing 30 tons) and trucks movement, as well as for storage of materials and installation of temporary construction camp;

2. Office building on B. Strochenovsky lane. Pit depth of $13.0 \mathrm{~m}$ was fixed by two floors connected by a system of racks and spacers;

3. Office building on Lefortovsky Val street. The pit depth of $20.0 \mathrm{~m}$ was fixed with four floors, moreover the two upper ones were connected by braces, and the two lower ones were attached by suspensions to spatial supporting structure, while the span between walls of the structure did not exceed $30.0 \mathrm{~m}$

4. Building on Stremnoy lane vl.29 was built according to the stages considered in the article;

5. For transport tunnels that have a large overall size, a variant has been developed in which only one spacer floor is used. According to the RF patent 2489550[2], the works are carried out in stages in such a way as to minimize the time when it is impossible to move over the pit.

As shown by the practice of using this method, it fully met expectations and showed sufficient efficiency.

\section{References}

1. Patent RF2220258

2. Patent RF2489550

3. B.V. Zhadanovskiy, S.A. Sinenko, Prospects of improving the technical level of concrete works in modern construction, (MGSU, Moscow, 2014)

4. P.P. Oleynik, B.F. Shirshikov, Design of construction organization and production of construction and installation works, Textbook for high schools (MGSU, Moscow, 2010)

5. Russian Federation Standard SP 12-136-2002

6. Russian Federation Standard SP 48.13330.2011

7. Russian Federation Standard STO NOSSTROY 2.33.14-2011

8. T.M. Shtol, Technology of erection for underground part of buildings and structures (1990) 